\title{
Tegyük helyére a globális kormányzást
}

\section{Dani Rodrik (2020): Putting Global Governance in Its Place}

The World Bank Research Observer, Volume 35, Issue 1, February 2020, Pages 1-18.

Dani Rodrik a The World Bank Research Observer 2020. februári számában megjelent tanulmányában egy olyan lehetséges globális kormányzási modellt vázol fel, melynek alapja a demokratikus államok müködésének elősegítése. A szerző amellett érvel, hogy a világgazdaságban lévő politikai kudarcok nem a nemzetközi együttmüködés hiánya miatt következnek be, sokkal inkább a nemzeti kormányzás hibáiból fakadnak.

Rodrik arra a kérdésre keresi a választ, hogy mikor kell a globális szabályokat a nemzeti különbségek fölé helyezni és közös megoldásokat elöírni? Némileg más kérdések is kapcsolódnak ezekhez a megállapodásokhoz - nem csak, hogy mely politikákra kell kiterjednie, de milyen típusú belpolitikai folyamatokat kellene ösztönözniük vagy megakadályozniuk.

Csábító lehet azt feltételezni, hogy az erősen integrálódott világgazdaságban a problémák egyre több nemzetközi együttmüködést és jobb globális kormányzást igényelnek. A szerző azonban felhívja a figyelmet a globális kormányzás lehetséges buktatóira. Egyrészt az interdependencia miatt gyakran elmosódik a határvonal a nemzetközi és a hazai között, másrészt továbbra is jelentős a nemzetek közti intézményi sokszínűség, aminek okai a különböző történelmi, kulturális vagy fejlődési pályákban gyökereznek. A sokszínűség tükröződik mind a preferenciákban, mind a világ működéséről alkotott eltérő elképzelésekben. Ezek viszont megnehezítik a megegyezést az országok számára a közös politikákról vagy szabályokról.

A nemzeti politikai döntéseknek globális hatásuk is lehet, másrészről viszont a globalizáció komoly korlátként (és/vagy lehetőségként) jelenik meg a politikai döntéshozatal különféle szintjein. Emiatt nehéz meghatározni, hol húzható meg a választóvonal azon politikai területek között, amikor a nemzetállamok tetszésük szerint szabadon cselekedhetnek, illetve amikor tevékenységüket nemzetközi megállapodások szabályozzák.

A gazdaságilag kölcsönösen függő világban számolni kell a spillover (tovagyürüző) hatásokkal, vagy a határokon átnyúló externáliákkal. Amikor az országok önállóan cselekszenek, maximalizálják saját hasznosságukat, gyakran figyelmen kívül hagyják a döntéseik során a más országokra gyakorolt hatásukat.

Rodrik kiemeli azt a két esetet, ahol a globális szabályozás révén minden ország jobb helyzetbe kerülhetne. Az első a globális közjavak esete. A közvetlen, belföldi hatások mellett a bel- és külpolitika együttesen hozzájárulhat globális haszon (vagy kár) létrejöttéhez, fogyasztói között nincsen rivalizálás, és nem zárhatók ki önkényesen egyes országok. Azonos politika esetén az egyes országok hozzájárulása a globális haszonhoz (vagy kárhoz) arányos az adott ország méretével. A legismertebb példa erre az üvegházhatású gázok (ÜHG) kibocsátása, amelynek éghajlati hatásai előnytelenül hatnak a globális közösségre. Amit ma teszünk, évszázadokig befolyásolja majd a klímát minden ember számára, bármely országban él. A CO2-kibocsátás csökkentésének költségei viszont már rövid távon felmerülnek az egyes országokban. Az emisszió csökkentésének haszna azonban csak a jövőben, hosszú évek múltán jelentkezik, amikor az alacsonyabb kibocsátás visszaszorítja az éghajlatváltozás által okozott károkat. A globális jólétet szolgáló intézkedésekből a világ nagy része profitál, de egyes országokra lebontva kevés vagy elenyésző kedvező hatást okoznak. Ezért az országok arra törekednek, hogy minimalizálják ezt a fajta 
tevékenységüket. Egy globális megállapodás által, amely korlátozza a hazai üvegházhatásúgáz-kibocsátás szintjét, minden ország kedvezőbb helyzetbe kerül, feltételezve, hogy országok kellően hasonlóak, vagy a felső értékek megfelelően vannak kalibrálva az egyes országok körülményeihez. Ez a logika alkalmazható sok más szakpolitikai területen is. A prudenciális pénzügyi szabályozás biztosítja, hogy a pénzügyi közvetítők ne vállaljanak túl nagy kockázatot, és a pénzügyi instabilitást kordában tartsák.

A második esetet a „beggar-thy-neighbor”, azaz más kárára jól járni igyekvő (BTN) politikák jelentik. A BTN-politika bevételáramlást eredményez a hazai gazdaságba a világ többi részéröl, miközben melléktermékként globális szinten hatékonytalanságot és holtteherveszteséget hoz létre. Olyan zéró összegü intézkedésekből áll, amelyek csak akkora előnyökkel járnak hazai szinten, amekkora károkat okoznak más államoknak.

Klasszikus példának számítanak az olyan bizonyos ritka nyersanyagok terén kialakított kartellek, amelyek monopolárakat szabnak a kereskedelmi partnereiknek.

A kereskedelempolitikában jól ismert példa az úgynevezett optimális vám, amelynek értelmében egy nagy ország az import (vagy az export) korlátozásával manipulálhatja kereskedelmi feltételeit. Egyensúlyi állapotban egyik ország sem képes kivonni a transzfereket a másik országból. De amikor mindkét ország megpróbál a másik kárára előnyösebb helyzetbe jutni, mindkettő kevésbé hatékony állapotba kerül.

Egy másik példa a merkantilista árfolyampolitikai intézkedések bevezetése. Feltételezett általános munkanélküliség mellett mindkét ország számára előnyös lenne a kereskedelmi többlet. Az országok megpróbálják alulértékelni saját valutájukat a kereskedelmi egyensúly javítása érdekében, de így az egyik ország által megszerzett kereskedelmi többlet a másik kereskedelmi hiánya lesz. Végül az ilyen erőfeszítések ellensúlyozzák egymást. Egyik országban sem lesz magasabb foglalkoztatás, de mindkettőnek viselnie kell a merkantilista gazdaságpolitika járulékos költségeit.

Az adóparadicsomok is hasonló példák lehetnek. Az adóparadicsom olyan joghatóság, amely kizárólag alacsony társasági adókulcsot alkalmaz, lehetővé téve a nemzetközi vállalatok számára az adókijátszást. Anélkül, hogy ösztönözné a fizikai befektetéseket, aláássa az országok adóalapját, amit közpénzekből, az adófizetők rovására kell kiigazítani. A globális kormányzás igyekszik megakadályozni az adóversenyt. Hasonló eset állhat fenn a személyi jövedelem- vagy a vagyonadóparadicsomok esetében is. A globális nyilvántartás, amely az összes pénzügyi vonatkozásban azonosítja a bankszámlák végső tulajdonosait, segítenék az adóigazgatást. A világ legtöbb országának előnyökkel járnának, de az adóparadicsomok rosszabb helyzetbe kerülnének.

Bár ezek a példák tökéletesen alátámasztják a globális kormányzás szükségességét, felsoroltakon kívül nem tartozik más politika ebbe a kategóriába. Talán az Egyesült Államok és Kína közti verseny a digitális technológiák által új területeket nyit meg BTN-politikák számára.

A jelenleg vitatott és politikusok figyelmét mostanában lekötő gazdaságpolitikák túlnyomó része nem BTN, annak ellenére sem, hogy gyakran próbálják annak mutatni.

A nem BTN-politikáknak a következő jellemzőik vannak: nem hoznak létre globális hatékonytalanságot, vagy ha mégis, annak közvetlen gazdasági költségeit a hazai gazdaság viseli. A jelenlegi gyakorlat szerint ezeket a politikákat nem szabályozzák nemzetközileg. A határokon átnyúló spillover hatások jelenléte önmagában nem indokolja az egyes nemzetek önállóságának korlátozását.

A nem BTN-n irányelvek közé tartozik az „Enrich-Thy-Neighbor”, azaz olyan tevékenység vagy politika, amely során az egyik ország a másik rovására nyereséget termel, de követi a „Beggar-ThyNeighbor" politikáját az adók kivetésében.

Egy jelentős kategóriája van a politikáknak: az export termékek támogatása. 
Rodrik amellett érvel, hogy legyen szó mezőgazdasági vagy ipari termékekről, az exporttámogatások nemzetközileg nem elfogadhatók. Az exporttámogatás ugyanis rontja a hazai ország, összesítve azonban javítja a külföld kereskedelmének feltételeit. A komparatív elönyöket tekintve aszimmetrikus hatások jelennek meg az egyes országok között. Ha az egyik külföldi ország komparatív előnyszerkezete az anyaországhoz hasonló, a kereskedelmi feltételeik együtt mozognak. Tehát például a mezőgazdasági exporttámogatások rosszabb helyzetbe hozzák a mezőgazdasági termékek nettó exportőreit a világ többi részén, miközben a nettó importőrök jobb helyzetbe kerülnek.

Három érv szól amellett, hogy miért kellene globálisan visszaszorítani az exporttámogatásokat. Az import egyoldalú liberalizációja kirívó példa. Amikor egy nagy ország egyoldalúan csökkenti behozatali akadályait, akkor általában kereskedelmi veszteséget okoz. Azok a külföldi országok, amelyek osztoznak ennek az országnak a komparatív előnyeiben, szintén kereskedelemi veszteséget realizálhatnak.

A támogatások, ellentétben az egyoldalú importliberalizációval, globálisan nem hatékonyak. Amikor a támogatások nem szolgálnak valódi gazdasági célt, a BTN-politikákkal ellentétben, a közvetlen költségeket az adófizetők és fogyasztók viselik.

A támogatások aláássák az egyenlő versenyfeltételeket a globális kereskedelemben. De az, hogy mi alkotja az egyenlő versenyfeltételeket, mi a tisztesség, nagyon is szubjektív. Természetesen, ha globális megállapodással meg lehetne állapítani, hogy mi az “igazságos”, észszerüvé válna a közös standardok létrehozása. Ehhez azonban hiányzik a közös értékrend.

A szerző megvizsgálta azokat a politikákat, amelyeket belföldi okok miatt alkalmaznak, de kedvezőtlen hatásokat okoznak más országokban. Közülük több, ellentmondásos következményeket okozó politikát már nemzetközi szinten szabályoznak. Néhány példa a teljesség igénye nélkül: szellemi tulajdonjogi védelem; olyan ipari politikák, amelyek nem járnak exporttámogatásokkal; a GMO-k, a hormonokkal táplált marhahús és más hasonló egészségügyi tilalmak; túlzott költségvetési megszorítások; laza pénzügyi szabályozás; importvédelem a foglalkoztatás elősegítése érdekében bizonyos iparágakban vagy régiókban; a társasági adó „nagyon alacsony” szintje (Írországhoz hasonlóan, ahol hatása lehet a hazai tőkeképzésre, nem pedig adóparadicsomok).

Ezen politikák belföldi gazdasági hatásai ex ante negatívak vagy legalábbis vitatottak, és jellemzően más országok számára is negatív hatásokat generálnak. Észszerű lehetne a globális kormányzás bevezetése ezeken a területeken, nehézséget jelent azonban az, hogy - mint az exporttámogatási ügyben - vannak erős kiegyenlítő érvek, amelyek nem utasíthatók el. Ma már széles körű egyetértés van abban, hogy az Egyesült Államok pénzügyi szabályozói 2007 előtt rosszul döntöttek a jelzálogkölcsönök és az árnyékbanki szektor kockázatvállalásában. De tekintettel az amerikai pénzügyi szektor befolyására a bázeli szabályok meghatározásában, egyáltalán nem biztos, hogy a pénzügyi szabályozás nagyobb mértékű nemzetközi összehangolása jobb eredményeket hozott volna.

Ezenkívül valóban előfordulhatnak olyan torzulások a piacon, amelyek indokolhatják ezen politikák használatát. Nem nyilvánvaló, hogy a kereskedelmi tárgyalók vagy a nemzetközi bürokraták bonyolult esetekben jobb döntést hoznának a belföldi törvényhozóknál.

A közgazdászok elsődleges érve a globális kormányzás mellett, hogy a globális szabályok megakadályozhatják az országokat abban, hogy a belpolitikai kudarcok megoldásához „,beggar thyself”, azaz önkárosító politikát alkalmazzanak.

Rodrik ezellen három ellenérvet sorakoztat fel. Először is, a globális szabályozás nem tud megbízhatóan különbséget tenni a „beggar thyself” és a gazdaságilag kívánatos politikák között. Ez különösen igaz azokon a szakpolitikai területeken, amelyek megkövetelik a jelentős helyi ismereteket az iparpolitikák vagy a pénzügyi elöírások tekintetében. Másodszor, még akkor is, ha erős a feltételezés, hogy az országok 
„,beggar thyself” politikát folytatnak, meg kell engedni, hogy a demokráciák elkövethessék saját „hibáikat”. A nemzetek feletti testületeknek az ilyen ügyekben való ítélethozatali lehetősége aláássa mind a demokráciát, mind a globális kormányzási megállapodások legitimitását. Harmadik, és ami talán a legfontosabb, valójában a nagyvállalatoknak, a nemzetközi bankoknak és a Big Pharma vállalatoknak aránytalan befolyásuk van a globális gazdasági kormányzásra. Naivitás lenne azt feltételezni, hogy a közérdeket előre helyeznék a saját érdekeiknek és szükségleteiknek megfelelő globális megállapodások kialakításával szemben.

A tárgyalások már nem egy szabadkereskedelmet folytató kormány és protekcionista vállalati érdekek között történnek, nemzetközi kötelezettségvállalásokkal. Ma a nagy nemzetközi cégek befolyásolják a nemzetközi politikai döntéshozatali folyamatot; gyógyszeripari vállalatok, amik szigorúbb szabadalmi szabályokra törekednek, pénzügyi intézetek, amik korlátozni kívánják az országok képességét a tőkeáramlás kezelésére, vagy multinacionális vállalatok, amelyek keresik azt a bíróságot, ami alkalmas a kormányokkal szembeni igények érvényesítésére. A külső korlátok felhasználása a belpolitika alakításához bizonyos költségekkel jár a demokratikus legitimitás szempontjából: megerősíti a nativista populisták üzenetét és a kozmopolita technokratáknak engedik át a szuverenitást.

A szerző amellett érvel, hogy a „globális közösség” nem határozhatja meg az egyes nemzeteknek, hogyan kellene mérlegelniük a hazai célok és prioritások között. Ez azonban nem zárja ki a globális beszélgetést a különféle előnyök természetéről és a feleket ért ártalmakról. Az ilyen beszélgetések hasznosak lehetnek a nemzetközi félreértések csökkentésében. Ha a kedvezőtlen gazdasági hatások jelentősek, más országok is képesek lehetnek meggyőzni a kormányokat, hogy jobb politikába kezdjenek. A nemzetközi párbeszéd lehetővé teheti egyes Coase-i alkuk megkötését, amikor más nemzetek veszteségei már meghaladják a belföldi hasznot.

Rodrik általános szabályként nem ért egyet azzal a következtetéssel, miszerint a multilaterális megállapodások segítik a demokráciák jobb müködését. Az elméletet megfordítva, normatív javaslatként használva azonban elképzelhetjük a globális gazdasági kormányzás alternatív koncepcióját, amely közvetlenül a nemzeti kormányzási kudarcokat célozza anélkül, hogy a globális kormányzásnak jelentős hatása lenne. Ezt nevezi a szerző „demokrácianövelő globális kormányzásnak” (DEGG), élesen elválasztva a „globalizációt elősegítő globális kormányzástól” (GEGG). A GEEG keretében elfogadhatunk minden külső szabályt, ami korlátozza a belpolitikai autonómiát, ha ennek eredményeként az országhatárokkal kapcsolatos tranzakciós költségek minimalizálódnak. A DEGG keretében csak azokat a kötelezettségeket alkalmazzuk, amelyek fokozzák a belföldi tanácskozást.

Az eljárási követelmények célja a belpolitikai döntéshozatal minőségének javítása. Ilyen követelmények vonatkoznak a globális diszciplínák mentén például az átláthatóságra, az érdekeltek széles körü képviseletére, az elszámoltathatóságra és a tudományos/gazdasági bizonyítékok hazai eljárásokban történő felhasználására vonatkozóan. Ezek az eljárási követelmények nem befolyásolják a végeredményt, ha az ország vámot vet ki, támogatást vagy bármilyen más „beggar thyself” politikát alkalmaz. Olyan megközelítést kell alkalmaznunk a globális együttmüködésre, amely tiszteletben tartja a nemzetek politikai terét és demokratikus döntéshozatali normákat céloz meg a harmonizáció helyett.

\section{Zsámár Klaudia ${ }^{1}$}

${ }^{1}$ egyetemi hallgató, Budapesti Corvinus Egyetem

DOI: 10.14267/RETP2021.02.24 